International Journal of Social Science and Economic Research

ISSN: $2455-8834$

Volume: 05, Issue: 07 "July 2020"

\title{
CITIZENSHIP AMENDMENT ACT (2019): INDIAN YOUTH'S VIEWS
}

\author{
${ }^{1}$ Aadyaa Shukla Tiwari, ${ }^{2}$ Professor Arunima G (Mentor) \\ ${ }^{1}$ The Shriram Millennium School, Noida \\ ${ }^{2}$ Jawahar Lal Nehru University \\ DOI: 10.46609/IJSSER.2020.v05i07.022 URL: https://doi.org/10.46609/IJSSER.2020.v05i07.022
}

\begin{abstract}
This paper analyses India's Citizenship Amendment Act 2019 (CAA) through legal and social perspective. It explores both sides of the debate discussing in detail about the arguments that have been established for and against the act. It also looks at religion based privileges- laws previously or currently implemented in India. An online survey was taken consisting of 150 participants falling in the age group of 15-34 years classified as Youth in India as per the Ministry of Statistics and Programme Implementation, Government of India (2017). The survey asked respondents questions regarding their age, gender whether they supported the act or not, their rationale behind their stance, views about protests and their main source of consuming news. The data collected has been analysed from diverse aspects such as age group, gender. Conclusions have then been drawn from the findings.
\end{abstract}

Keywords: Citizenship Amendment Act 2019, Perceptions, Opinions, Online survey, Youth views

\section{INTRODUCTION}

This paper analyses India's Citizenship Amendment Act 2019 (CAA) and studies the perception of young people towards the act and tries to find out the underlying reasons behind their views and opinions on the topic. While there have been extensive news and feature articles on the issue but there is a lack of analytical papers and academic work that examines the topic in a holistic manner. This paper aims to fulfill that gap to some extent.

\section{RESEARCH METHODOLOGY}

This paper is based on secondary research of papers, books, newspaper/magazine articles on the topic. Thereafter the paper attempts to compare and contrast the findings through an online survey of 150 young people between the age of 15-34 years (criterion of youth followed by 
International Journal of Social Science and Economic Research

ISSN: $2455-8834$

Volume: 05, Issue: 07 "July 2020"

Government of India), analyzing their perceptions and opinions on the CAA. Primarily convenience sampling was used although more respondents from teenage were chosen, anticipating their higher readiness to share and pursue peers to respond, some representation was also provided to other age groups for having a fuller view from youth population of India. Online survey tool using Google Forms was used and its inbuilt tools were used for analyzing the data.

\section{BACKGROUND- CAA \& RESPONSE}

On Dec 11, 2019 the Parliament of India passed a Citizenship Amendment Bill which had been introduced in the lower house by Home Minister Amit Shah. The newly passed act amended The Citizenship Act, 1955, thus providing citizenship to hitherto illegal immigrants from Afghanistan, Bangladesh and Pakistan who practiced Hinduism, Sikhism, Christianity, Buddhism, Jainism and Zoroastrianism, who entered India on or before the last day of December 2014. As the Act stated:

"Provided that any person belonging to Hindu, Sikh, Buddhist, Jain, Parsi or Christian community from Afghanistan, Bangladesh or Pakistan, who entered into India on or before the 31st day of December, 2014 and who has been exempted by the Central Government by or under clause (c) of sub-section (2) of section 3 of the Passport (Entry into India) Act, 1920 or from the application of the provisions of the Foreigners Act, 1946 or any rule or order made there under, shall not be treated as illegal migrant for the purposes of this Act;". ${ }^{1}$

Post being passed, the Act prompted outrage and protests across India.S everal petitions argued that the law was illegal, as it granted citizenship on the basis of religion - which went against India's secular values as mentioned in its constitution. A group of political parties, civil society and Muslim groups are opposing this act. ${ }^{2}$

The United Nations Human Rights Office of the High Commissioner expressed concern that Indian's CAA is fundamentally discriminatory in nature. ${ }^{3}$

Reacting to the criticism and protests, Indian Home Minister Amit Shah stated that people are being misled on CAA and not a single Indian citizen will lose their citizenship. The CAA is meant to enable and empower stateless refugees and is not meant to deprive any Indian citizen. ${ }^{4}$

\footnotetext{
${ }^{1}$ The Gazette of India, No. 71, Dec 12, 2019

${ }^{2}$ Citizenship Amendment Act: Court refuses to put controversial law on hold, BBC News, Jan 22,2020

${ }^{3}$ Jeremy Laurence, Spokesperson, UNHRC, Press Briefing on India, Geneva, Dec 13, 2019

${ }^{4}$ Press Release, Press Information Bureau, Government of India, Dec 17, 2019
} 
International Journal of Social Science and Economic Research

ISSN: $2455-8834$

Volume: 05, Issue: 07 "July 2020"

With widespread protests there was violence and police brutality. The two historically Muslim universities, Aligarh Muslim University and Jamia Millia Islamia university, where the police response was most violent — firing tear gas and beating students. ${ }^{5}$

The women led protest in Delhi's Shaheen Bagh went on for 101 days. The protesters finally were forced to depart from their iconic sit-in site in the wake of the COVID-19 crisis, However, the protest overturned several stereotypes and inspired similar protests all over the country. ${ }^{6}$

At the same time, in the Indian state of Assam, people were protesting as they felt that if the CAA became operational, a previous accord (the Assam Accord) would be rendered ineffective as the cut-off date of 1971 for identifying illegal immigrants would become void. Therefore, the state that borders Bangladesh would have to accept hundreds of thousands of immigrants who entered the country between 1971 and $2014 .^{7}$

Ever since its introduction, passage and assent by the President of India, the CAA has polarised the country as media, social media and physical gatherings witnessed heated debates for or against the Act.

\section{PRIVILEGES BASED ON RELIGION IN INDIA}

While no reservation on the basis of religious lines exists on the national level, several Indian states have implemented it. The Tamil Nadu government allotted 3.5\% of seats each to Muslims and Christians, in 2007 through an ordinance (Christians however gave up their part of the quota, and their share was given to Hindu backwards)

In 2004 Government of Andhra Pradesh introduced a law enabling 4 percent reservations for Muslims. This law was upheld by the Supreme Court in an interim order in 2010 but it constituted a Constitution bench to look further into the issue. The referral was to examine the constitutional validity of quotas based on religion. It was subsequently squashed in 2012. Kerala Public Service Commission has a quota of $6 \%$ for Muslims. Religious minority (Muslim or Christian) educational institutes also have 50\% reservation for Muslim or Christian religions.

The Union Government on 22 December 2011 announced the establishment of a sub-quota of $4.5 \%$ for religious minorities within the existing $27 \%$ reservation for Other Backward Classes.

\footnotetext{
5 'This Is Not Just a Muslim Fight.' Inside the Anti-Citizenship Act Protests Rocking India, Sanya Mansoor \& Billy Perrigo, TIME, Dec 19, 2020

${ }^{6}$ Shaheen Bagh protesters: Showing the way, Zia Us Salam, The Frontline, Apr 24, 2020

7 Anti-CAA Protests and State Response in Assam: Identity Issues Challenge Hindutva-based Politics, Chandan Kumar Sarma \& Obja Borah Hazarika, Economic \& Political Weekly, Volume 55, Issue no. 14, Apr 04, 2020 
International Journal of Social Science and Economic Research

ISSN: $2455-8834$

Volume: 05, Issue: 07 "July 2020"

The reasoning given was that Muslim communities that have been granted OBC status are unable to compete with Hindu OBC communities. However, it was never implied.

\section{ARGUMENTS AGAINST CAA}

The Citizen Amendment Act has been criticized on several counts, the most common being that it is unconstitutional. It is argued that the CAA is against the Articles 25, 26 and 27 of the Constitution of India that guarantee religious freedom. ${ }^{8}$

It also violates article 14 which grants the fundamental right to equality of all persons, as it excludes Muslim illegal immigrants and promising to give illegal immigrants of other religions citizenship. ${ }^{9}$

According to the CAA, Muslims don't face religious persecution in Afghanistan, Bangladesh and Pakistan, however, that does not hold true for certain sects-Shias, Ahmadiyyas, etc., who may need to enter India in order to avoid persecution. A constitutional amendement in Pakistan has declared Ahmadiyas to be non-Muslims, while the Kerala high Court has declared them as Muslims. Similarly, many people of Bangladeshi origin were born in Assam and do not have any roots in Bangladesh. Bangladesh has refused to accept them. Therefore, it is more of a humanitarian problem than a legal one. ${ }^{10}$

Since Independence, India has been at the forefront of the Non-Alignment Movement. It has constantly maintained its position as a global leader in protection of human rights, minorities and social justice. However, the provisions of CAA are in complete contrast to India's consistent position with respect to these issues. This has contributed to a 10 place fall in India's rank in the Economist Intelligence Unit's Democracy Index 2019. The survey published on January 22, 2020 attributes the primary cause of "the democratic regression" to "an erosion of civil liberties in the country". ${ }^{11}$

\section{ARGUMENTS IN FAVOUR OF CAA}

The biggest argument in favour of the CAA was made by the Indian Home Minister in Parliament where he argued that the Bill did not aim to grant citizenship to a particular

\footnotetext{
${ }^{8}$ Statelessness in India-Seeking Solutions in International Law, Vatsal Raj, Cambridge International Law Journal,11 February,2020

${ }^{9}$ Citizenship (Amendment) Act 2019: What is it and why is it seen as a problem, Economic Times, 31 December,2019

${ }^{10}$ Secularism and the Citizenship Amendment Act,Dr. Abhinav Chandrachud

${ }^{11}$ India drop 10 ranks to 51st position in Economist Intelligence Unit's Democracy Index, Saira Aslam, The Hindu, Jan 22, 2202
} 
community, but instead to a class of people that fled Afghanistan, Pakistan and Bangladesh owing to religious persecution. He went on to state that the Bill will grant citizenship to the class, who faced atrocities and a challenge to safeguard the dignity of their women. ${ }^{12}$

Defending constitutionality of the Act, former Solicitor General of India, Harish Salve said that selection of the countries on the ground that they were countries with a declared state religion, and hence the religious persecution of declared minorities in those countries amounted to reasonable classification. He claimed that the citizenship law, prior to CAA, excluded everyone from acquiring citizenship and relaxation has now been made in order to allow religiously persecuted minorities from the above mentioned countries to apply for citizenship. According to him such a relaxation is perfectly valid under Article 14 of the Constitution. ${ }^{13}$

The strong proponents of the CAA point out that the CAA does not affect or take away the citizenship of any Indian Muslims. They also allege that Indian Muslims are being misled with regard to their citizenship and constitutional rights. ${ }^{14}$

\section{FINDINGS FROM THE PRIMARY SURVEY}

The survey asked respondents to answer 6 questions about:

- Age

- Gender

- Perception about CAA

- Rationale behind their opinion

- Opinion about protests related to CAA

- Sources of consuming information

The $60 \%$ of respondents were female and $40 \%$ male. More than two-third of them were in the age group of $15-18$, followed by other age groups.

\footnotetext{
${ }^{12}$ Does Article 14 apply to non-citizens? Sumeet Kaul, The Times of India, Dec 12, 2019

${ }^{13}$ Harish Salve to NDTV, Dec 11, 2019

${ }^{14}$ Citizenship (Amendment) Act does not affect any Indian citizen, including Muslims, clarifies Home Ministry, Hindu Business Line, Dec 17, 2019
} 


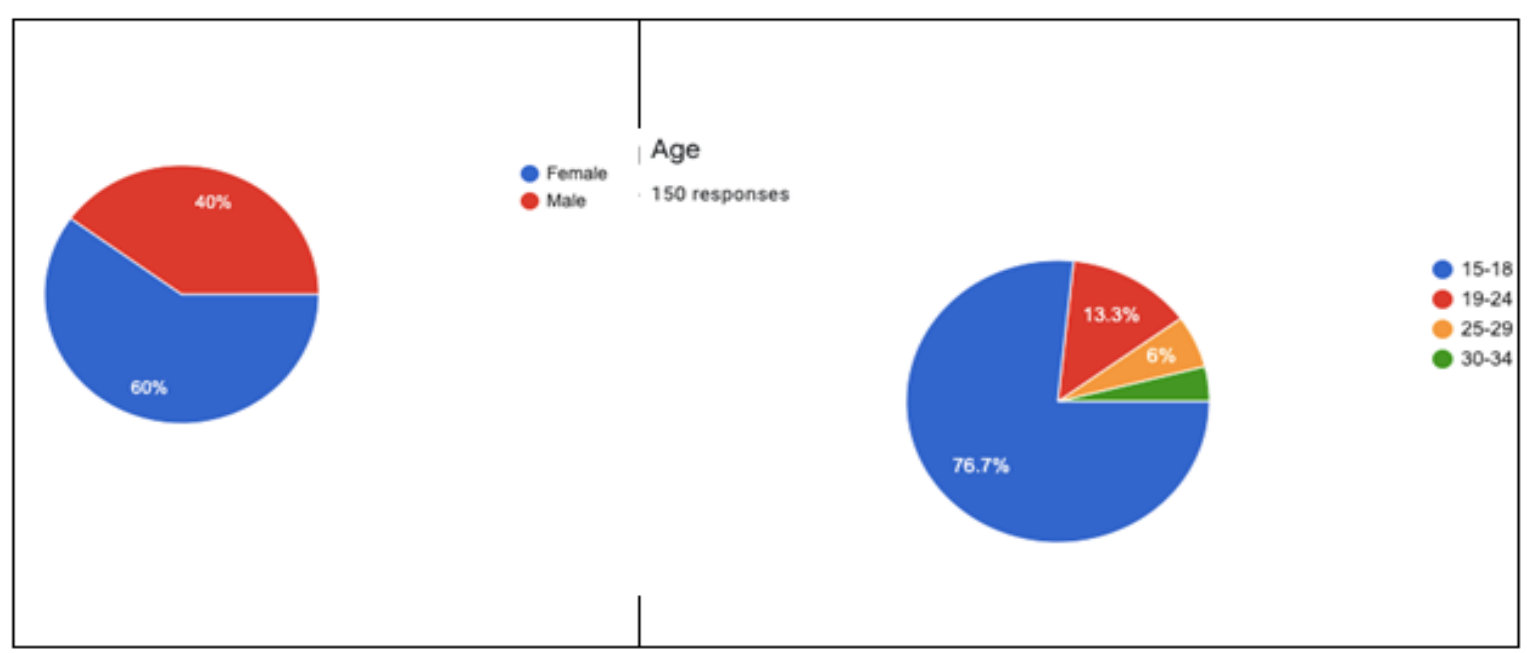

That the topic resonated across several age groups is also an indicator of its prominent presence in the minds of Indian youth.

On the question of whether they supported CAA or not, while a majority, $56 \%$ of the respondents were against it, a sizeable $44 \%$ of them were for the Act.

\section{Do you support the CAA(Citizenship Amendment Act)? \\ 150 responses}

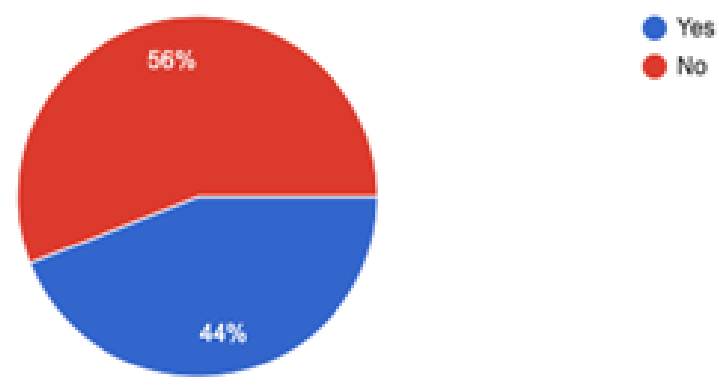

According to an IANS-C Voter snap poll taken between December 17 to 19, 2019, 62.1 per cent of people across the country said that they were in support of the CAA while 36.8 per cent people said that they were against it.

The results from IANS-C Voter survey are in contrast to the results received from the primary survey done for this paper. This could be possibly due to difference in time of conducting the two surveys, while the IANS-C Voter one was done very close to passage of bill while the survey conducted for this paper was done in 2020 in the midst of Covid-19 pandemic. Another 
key difference between both surveys is that the former could be taken by Indian citizens of all age groups, while later was strictly restricted to the youth demographic of India.
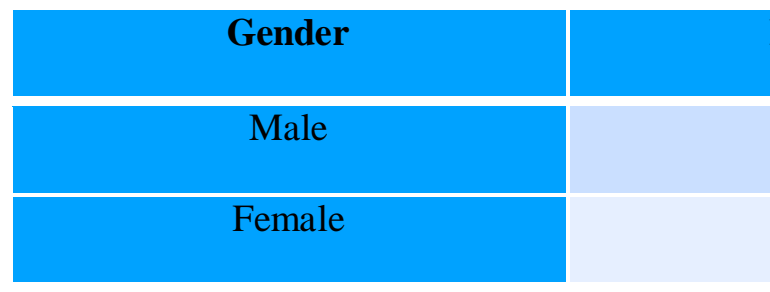

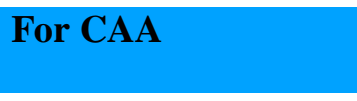

$55 \%$

$37 \%$
Against CAA

$45 \%$

$63 \%$

However, the results get interesting when we drill down the data on gender $55 \%$ of male respondents support CAA while $63 \%$ of female respondents are against CAA. This indicates that male respondents are more polarized on the issue than women who seem to be decisively against the Act.

A break-up of data by age group shows that the age group 19-24 is the one that seem to be more supportive of CAA than other age bands.

\begin{tabular}{|c|c|c|}
\hline Age Group & For CAA & Against CAA \\
\hline $15-18$ & $44 \%$ & $56 \%$ \\
\hline $19-24$ & $55 \%$ & $45 \%$ \\
\hline $25-29$ & $33 \%$ & $67 \%$ \\
\hline $30-34$ & $50 \%$ & $50 \%$ \\
\hline
\end{tabular}

While it may be difficult to infer that the youth of India leans more towards anti-CAA views, the two surveys are a fair statistical representation of polarization being observed on the issue. It also gives a sign that the polar views on the topic could continue as the youth of today go on to become the leaders and responsible citizens of tomorrow.

Thereafter, an attempt was made to understand the underlying reasons that motivated people to vote for or against the CAA. The respondents were given multiple options to choose from. The options were derived from major reasons identified during the secondary research and as stated earlier in this paper. The respondents who had chosen 'yes' could not choose options against the CAA and vice versa. The respondents were also given opportunity to state their own reason if they did not agree with any of the options. 
As can be seen the graphic representation of results later, close to $34 \%$ of the 85 respondents who were against CAA felt it discriminated against the Muslims. A close set of around 33\% young people felt that the Act was unconstitutional. Around $11 \%$ chose that they were against CAA as it brought cut off for citizenship from 1971 to 2014.

However, as we have seen from the secondary research that this particular reason impacts more the state of Assam. Still it is interesting to learn that it remains the third largest reason for the respondents that are against CAA. Around $8 \%$ of respondents felt since CAA ignores minorities from countries like Sri Lanka and Myanmar they don't support it. Around 2\% of the survey takers who were against CAA chose other reasons, stating disagreement with how CAA is being implemented and expressed fear it would hamper livelihoods for millions of people.

The aspect of livelihood was also observed during secondary research where a paper stated that vagueness in CAA has angered people in the northeast because many of the "illegal migrants" were economic migrants and not necessarily those persecuted on the basis of religion. ${ }^{15}$

If yes, why?

66 responses

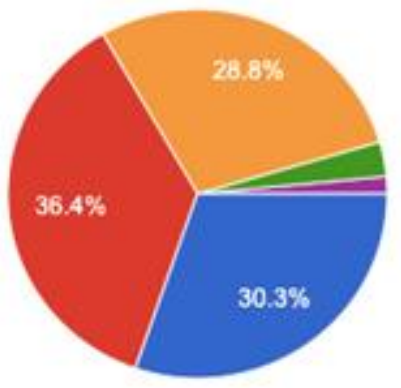

It will reduce radical millitant activities and curb terrorism

It provides citizenship rights to persecuted minorities from Bangladesh,Afghanistan and Pakistan It will help in taking action against illegal immigrants

All above

All of the above

As mentioned earlier, the survey also recorded the reasons why those who were in favor of CAA felt so. In this case there were three major reasons each being listed close to each other as the primary reason. The most voted one, that the CAA provides citizenship right to persecuted minorities from Afghanistan, Bangladesh and Pakistan, garnered agreement of $36 \%$ supporters of CAA. However, not far behind at 30\% were those who felt that the CAA will reduce militant activities and curb terrorism. Closely following this rationale at $28 \%$ was that the Act will facilitate action against illegal immigrants. Around 6\% felt that the CAA will accomplish all the above tasks and hence rested their support in it.

\footnotetext{
${ }^{15}$ Professor Chinmay Tumbe, Professor of Economics at Indian Institute of Management-Ahmedabad, and author of India Moving: A History of Migration
} 
The question of protests related to CAA gave some very interesting results, although $44 \%$ of respondents were in favor of the Act still a decisive $76 \%$ felt that protests were justified if they did not put general public to inconvenience. This goes on to show that a large majority of youth recognize that people who dissent with an issue have a right to protest.

\section{Which source do you use most to get news?}

150 responses
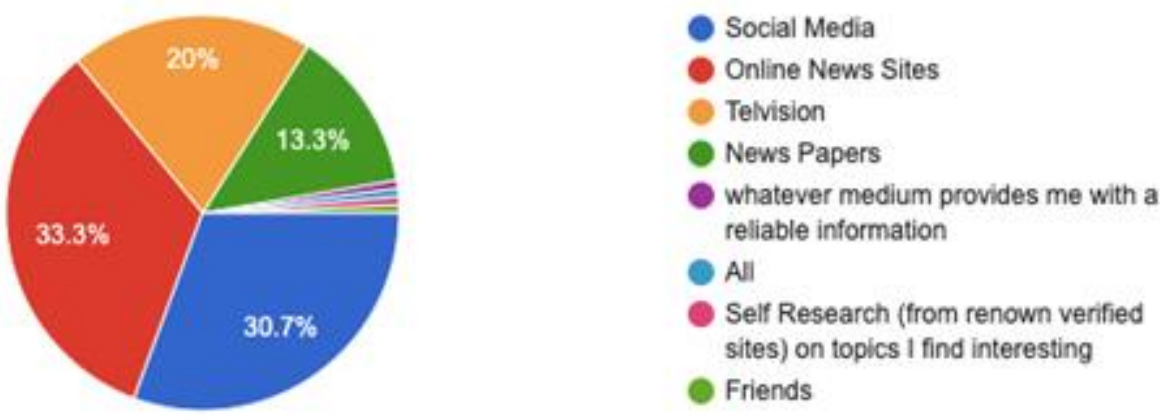

The final question although not directly related to the CAA was asked to understand the information consumption sources of the young people. Often it is mentioned that these impact the view point of the audience to a large extent. As can be seen in the finding the country's youth are highly dependent on online and social media channels for gathering their news and information. This possibly shows how important is that correct facts and not misinformation is allowed to be disseminated via these medium. In the case of the CAA both government and those against the law alleged campaigns of misinformation flowing through these channels, this study thought it useful to share data on this aspect too.

Please choose the statement you agree most with:

150 responses

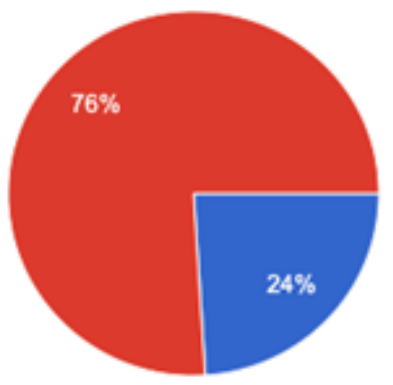

Protests against CAA are not justified

Protests are justifled but it should not put general public to inconvenience 
International Journal of Social Science and Economic Research

ISSN: $2455-8834$

Volume: 05, Issue: 07 "July 2020"

\section{CONCLUSIONS}

- The CAA has polarized the nation including the youth of the country with big blocks of people on both sides of the divide. The polarization is more stark in case of male while women respondents were found to be decisively against the CAA.

- The respondents in age band of 19-24 seemed more in favor of CAA, while the respondents in age band of 25-29 seemed less in favor of CAA than others. However, it is a small sample to decide conclusively.

- While the Act will provide citizenship to non-Muslim illegal immigrants from Afghanistan, Bangladesh and Pakistan, more than half of people supporting the CAA do so as they feel it will lead to curbing of terrorism and illegal immigration. The time can only tell whether these expectations would be met out of this law.

- Although one-third of those against the CAA feel so, through secondary research this study has observed that the way CAA has been drafted it is not unconstitutional as it argues it is benefitting a persecuted class and not people from specified religions.

- The CAA is seen by a wide section of youth that will lead the country in future, as being anti-Muslim despite this being repeatedly denied by the Government.

- Almost two-thirds of Indian youth including those who are in favor of CAA feel that people against it have the right to protest in a manner that does not put the general public to inconvenience.

- The CAA does not address the issues faced by north east state of Assam and immigration due to economic reasons. Although, it is a law now, the issues arising due to it will need democratic resolution by the government of India.

- Questions pertaining to its implementation are rife due to no proper plan having been proposed by the government. The looming global recession due to the Covid-19 pandemic which will undoubtedly rock India's economy will only put the act poised to cost thousands of crore more under scrutiny.

- Online News Sites and Social Media were the most popular mediums of news used by the youth indicating the dying influence of traditional mass media like Television and News Papers.

\section{LIMITATIONS OF THE STUDY}

- The CAA has an inherent link with NRC- National Register for Citizens. This study has not gone into that dimension and this could be subject of a future study.

- This study has not studied the linkage between protests and violence/rioting that followed, as it is a separate topic that needs exclusive exploration. 


\section{ANNEXURE}

According to data:

$76.7 \%$ survey takers were in $15-18$ age group,

$13.3 \%$ were in $19-24$ age group,

$6 \%$ were in $25-29$ age group,

$4 \%$ were in $30-34$ age group.

According to data:

$40 \%$ of survey takers were male

$60 \%$ of survey takers were female

According to data?:

$78 \%$ of survey takers were in High School or had graduated from High School

$13.3 \%$ of survey takers were enrolled in Graduate courses or had Graduate degrees

$8.7 \%$ of survey takers were enrolled in Post Graduate courses or had Post Graduate degrees

According to data:

$34.1 \%$ out of the survey takers who were against CAA said it discriminated against muslims

$32.9 \%$ out of the the survey takers who were against CAA said that it was unconstitutional

$10.6 \%$ out of the the survey takers who were against CAA said it brought cut off for citizenship from 1971 to 2014 
$8.2 \%$ out of the survey takers who were against CAA said It does not take care of minorities from Srilanka, Mynamar, Bangladesh

$4.2 \%$ out of the survey takers who were against CAA said other reasons

According to data:

36.4\% survey takers who supported CAA said it provides citizenship rights to persecuted minorities,

$30.3 \%$ survey takers who supported CAA said it will reduce radical millitant activities and curb terrorism,

28.8\% survey takers who supported CAA said it will help in taking action against illegal immigrants ,

$4.5 \%$ survey takers who supported CAA gave other reasons

According to data:

$76 \%$ believed protests against CAA were justified

$24 \%$ believed protests against CAA were not justified

According to data:

33.3\% used Online News Sites

$30.7 \%$ used Social Media

$20 \%$ used Television

$13.3 \%$ used News Papers

$2.7 \%$ used other sources 